\title{
Religion Amidst the Killings of Albino Persons in Tanzania
}

\author{
Elia Shabani Mligo \\ University of Iringa, Tanzania
}

\begin{abstract}
Tanzania is one of the so-called “developing countries” in Africa. According to the census of 2012, the country has a population of more than 44 million people. Albinos persons (people with skin impairment) are included within this population. In these days, the Tanzanian society witnesses dreadful killings of people with albinism just for cultural and traditional reasons. The major claim purported by killers is mostly economic, that some organs of people with albinism can be used by business people to acquire more profits in their businesses. Following this reason, people with albinism live in a very suspicious life because most of them have been hunted and murdered. Their human dignity has been jeopardized in favor of material wealth. Since scarce researches, if any, have been conducted in regard to the role of religion towards the dignity and value of people with albinism in areas of theology and religion, this paper provokes theologians and scholars in various professions towards discussing and analyzing critically the role of religion in the midst of horrible incidences of violence facing people with albinism. The major question is the following: How does religion deal with differences in the Tanzanian society to promote human dignity and mutual life among people despite their differences?
\end{abstract}

Keywords: Albinism, albino persons, human violence, religion, human dignity, difference.

\begin{abstract}
Albinism
Before engaging with this topic in a more detail, it is important that people first understand briefly what albinism is and how it happens. In actual fact, Albinism is a scientific terminology to explain what happens when the fetus inherits the recessive gene for skin color. The condition resulting from this genetic inheritance does not affect only human beings, but also all mammals and some reptiles, birds, fish, and amphibians (Magrams, 2009). Since albinism is accompanied by some peculiar features in the body of the affected person, such as white hair, milky skin, and pink eyes, albinism is assigned a difference from what is considered "normal". For that reason, the so-called "normal" people approach people with albinism with derogatory attitude (Magram, 2009). Hence, as it will be noted in the discussion below, this difference and its rare occasion are some of the major reasons for witchdoctors to capitalize their beliefs on albino persons.
\end{abstract}

\section{Religion and Human Violence}

After describing in brief what entails albinism, now turn to looking at the killings of people with albinism. In fact, the killing of people with albinism is considered one of the forms of human violence. Here people can ask: How should they understand violence at the encounter with fellow human beings with albinism? Is it

Elia Shabani Mligo, PhD, Senior Lecturer in Contextual Theology, University of Iringa.

Correspondence concerning this article should be addressed to Amani Centre, P.O.Box 958, Njombe Tanzania. E-mail: eshamm2002@yahoo.co.uk. 
something material, or something imaginable? What forms does it take? In fact, violence takes a multifaceted appearance. However, in this paper violence will be understood as

"An act of aggression that inflicts harm on an individual or community. In whatever the case, violence can be planned or unplanned. It can be small or large in scale. At the individual level, violence may cause physical disfigurement or death, while at the societal level, psychological discontent, residential displacement, or large scale carnage” (Nyaundi, 2010, p. 124).

Hence, as an act of aggression, violence is, in most cases, unpleasant to the one it is inflicted.

Moreover, violence can manifest itself in various forms depending on context and purpose of the crime. The African theologian Nehemia Nyaundi (2010) states: "Traditional forms of violence in Africa include murder, rape, assault, robbery with violence, and burglary” (p. 124). According to Nyaundi, most of these forms of violence have their major origins. Some of these sources are "religion, economics and politics" (Nyaundi, 2010, p. 124). Hence, following Nyaundi's suggestion, this short paper provokes scholars of religion to concentrate on murder and the role of religion in relation to this form of violence in a Tanzanian context, and any other place in the world.

Some important questions to think about are the following: How can people reconcile the religion that worships the Supreme Being and claims to enhance life with the violence inflicted by its adherents in the name of that same religion? Is violence part of the definition of that religion? If not, why should violence be tolerated in the name of a particular religious belief? Nyaundi (2010) again reminds people about the September 11 carnage in the United States:

"Before the carnage of September 11, 2001 in the United States few people would have imagined that sentiments of hatred between people of different religions, cultures, nations and races could have such devastating effects. That religion has the potential of causing that degree of violence is now, therefore, no longer in doubt” (p. 123).

For Nyaundi, religion is one of the major instruments of violence within societies. It is one of the causative agents of misunderstandings and human trafficking. The major question, according to Nyaundi (2010), is not whether one should ascribe violence to religion, but "rather how religion originates violence and the frequency with which that happens" (p. 123). Therefore, in this paper, for the sake of our discussion, the writer elaborates briefly the way in which traditional (religious) beliefs among people who are responsible in the emergence of violence among people with albinism in the Tanzanian context. This elaboration aims at provoking people towards engaging further into a discussion to whether religion plays any role towards sustaining human value and dignity.

\section{Religion and Albino Killings In Tanzania}

Having introduced the relationship between religion and human violence in the above paragraphs, now turn to surveying some mechanisms of killings of people with albinism in the Tanzanian context. In actual fact, a belief in the power to harm other people through witchcraft or mystical powers is widespread in most African societies apart from Tanzania, especially in rural areas. Some have argued that this kind of belief is catalyzed by illiteracy among most African rural societies. However, this practice or belief permeates the whole society, even among literate people.

In Tanzania, this belief permeates all ethnic groups within the country. Some more traditionally conservative ethnic groups have higher rates of killing incidences due to witchcraft or the use of traditional 
mystical powers. Ralph Tanner in his article called “Ideology and the Killing of Albinos in Tanzania” reports:

"By June 2009, some 48 Albinos had been killed by groups of Sukuma in north-west Tanzania so that parts of their bodies could be used in the preparation of supposedly protective 'magic' medicines which could be used to relieve a range of suspected and real misfortunes, ranging from witchcraft to the prevention of rain and the spread of AIDS as well as to increase the possibilities of success” (Tanner, 2010, p. 229).

Tunner's research indicates the seriousness of the problem not only to the Sukuma people, but also to the whole country and its inhabitants.

\section{Bases For the Killings Of Persons With Albinism}

At this juncture, people question the bases for the resurgence of these killings. What are the bases for these acute killings? The killings of people with albinism in Tanzania are most likely based on beliefs and traditional practices. Through these traditional beliefs and practices people can discern two other major bases for the killings of persons with albinism in the Tanzanian context. First, the killings erupt more likely because there is a prevalence of sameness among people whereby difference is rare and plays a secondary role. The killings are done because the responsible people construct differences and use those differences for their own material gain. Khalid Magram (2009) reports: "Many believe [that] prominent Tanzanian businessmen [sic!] are amongst the clients of the witchdoctors. Some businessmen were arrested accused of killing albinos, however, no one has faced trial as yet”. Magram's report indicates that the killing of people with albinism is not only limited to illiterate people in Tanzania, but also spreads among some literate businessmen and women who believe in the instructions provided to them by the consulted witchdoctors. In this situation the prevailing sameness is just normal; but the rare emerging difference in skin and eye color is constructed to enhance people's material gain.

Second, the killings of persons with albinism are based on people's situation of poverty and their endeavors to search for abundant wealth. One of the areas highly accused of killings of people with albinism in Tanzania is the western part of the country whereby mining and fishing activities are prominent. Magram (2009) reports thus: "Miners, businessmen, and fishermen with black magic beliefs are accused to increase demand for body parts in western Tanzania, location famous for its diamond mines in the world". This statement means that the killing of albino persons is associated by particular beliefs about the functionality of albinos' body parts in the increase of one's fortune in business, mining, and fishing activities.

Boniface Magessa, in his article called "The Killings of albino in Tanzania" published in Activist/Entrepreneur magazine of Friday, December 19, 2008, reports the same view. Magessa (2008) reports:

"As Warren Baffet and Billy Gates work hard to maintain their billionaire status in the world, back home in Tanzania, some greedy, heartless gold miners and fishermen in the Lake Victoria zone are trading in the body parts of albinos, which are controversially reported to enable them catch more fish and strike the precious stones more easily and in huge quantities”.

What do the killers do with the body parts of people with albinism? In fact, what is mainly done is the use of amulets made up of body parts of albino persons in belief that they will enhance good luck in people's economic activities. The Economist newspaper of 17 January 2009 reports that after the body parts of people with albinism have been obtained, the "skin and flesh are dried out and set into amulets and the bones ground down into a powder. Artisanal miners in the gold and diamond fields directly south of Lake Victoria are the main buyers”. Therefore, this practice is linked with magical medical practices done by people out of belief to strike more gold (albino bones) and attract more fish for fishermen and women (albino hair) (Daily News, 2008). 


\section{The Resurgence Of Albino Killings}

Having briefly described the bases and use of albino body parts above, people now look briefs on the resurgence of albino killings within the Tanzanian context and the efforts of the government to counteract such killings. The spread of the killings of Albino persons is not limited to the Sukuma area around lake Victoria. Some other regions in Tanzania have been reported to have such incidences. These regions include: Musoma region located in further north bordering with Kenya; Kagera region which borders with Congo, Rwanda and Burundi; and Mbeya region located in the southern way towards Zambia and Malawi (Daily News, $2^{\text {nd }}$ October 2008). The killings of persons with albinism now transcend the boarders of Tanzania towards the nearby countries of Uganda, Kenya and Burundi (The Economist, 17 January, 2009). This means that after the outbreak of the killings at the Sukumaland, its spread to other places has been very fast causing people with albinism to live a suspicious life.

\section{Efforts By the Tanzanian Government}

What efforts has the government made towards preserving and enhancing the value and dignity of people with albinism? In fact, there has been great efforts by the Tanzanian government to counteract the killing incidences praised even by the international witnesses, such as, the Parliament of European Union (European Parliament, 2009). However, if viewed more closely, such efforts prove to have a very minimal success. This is because the killing of albino children and adults still continues, especially around Lake Victoria among the diamond miners, businessmen and women, and fishermen. Some of the reasons for the difficulty to combat the killings are the following: First, albinos live in African (Tanzanian) communities whereby they are strongly linked to them in a communal life despite their unfriendliness. This means that albinos have no means of escaping the community sense of the Africans. Second, the killings are associated with traditional beliefs strongly held by people living with people with albinism. The belief and trust in the witchdoctors can hardly be separated from people that are economically greedy and presumptuous. In whatever the case, the killing of albinos is still illegal according to the Tanzanian law ordinances. One individual is not allowed to take the life of another individual in whatever purpose may be.

Hence, the major issue of discussion is the following: If the efforts of the Tanzanian government to prevent the killings are still very minimally successful, where does the society heading? What is the role of religion towards the enhancement of human value and dignity despite the existing differences among people? Magessa shows the possible direction of the Tanzanian society if the various organs in Tanzania, including religion, will not address the existing butchering of albinos. Magessa (2008) maintains:

'It is the appalling truth that proves how our nation is closely turning into a 'garden of evils' as lust for quick wealth, drives some Tanzanians into murdering the rare albinos, who in addition to the suffering occasioned by skin disorder, are now living in perpetual fear of being kidnapped and murdered”.

\section{Religion and Human Dignity Amidst Albino Killings}

The above description indicates that the life of people with albinism is under direct attack in Tanzania and the neighboring countries. The theologian Bernard Evans categories two forms of threats to human dignity and life: the direct attack to human life, and the character leading to the diminishing of the quality of human life. Direct attacks to human life include such activities as abortions, assisted suicide and euthanasia, embryonic stem cell research, death penalty, and war (Evans, 2006, pp. 18-23). Adding to Evan's list above, the killing of 
people with albinism for business purposes and the killing of old people with red eyes for superstitious reasons are also attacks upon human dignity and life. These also are unacceptable deeds upon human beings.

As a matter of fact, Tanzania is a country that does not affiliate with any religion politically. However, Tanzanians are people with various religious backgrounds. Some are Christians, some are Muslims, and some are Traditional religious believers, while a few of them claim to be atheists. The question that intrigues the writer falls upon the role of religions embraced by Tanzanians upon such discriminating and threatening deeds inflicted upon human life. The killing of people with albinism is not done in a vacuum. It is done in places where sacred religious scriptures are preached and people claim to be religious believers. Moreover, some of the killings are done within families. Family members most likely plot with killers in order to obtain albino organs for economic purposes. However, little efforts are taken by those religions towards curbing the dehumanizing killings of people with albinism and old people with red eyes who are considered witches. The reluctance of religions within Tanzania to engage fully in the preventions of the killings leads people to questioning their claim to bring harmony among people of every kind. Is the Supreme Being that they worship and adore a merciful Being or a Being that enhance the devaluation of human dignity and value?

The theologian Bernard Evans (2006) further writes:

"Human dignity is the bases for claiming all human life to be sacred. It is at the core of our understanding of the human person - her unique relationship to God, her special place within creation, her vocation as communion with God. Respecting the dignity of every person is a pre-condition for a healthy human community” (p. 23).

Following Evans' words above, the claim of Tanzania to be a peaceful country is put into jeopardy because human life and dignity have not equally been respected among all people. According to the writer's understanding, peacefulness does not only rest upon the absence of civil wars or wars with neighboring nations. It is also the absence of wars and violence against human life and dignity.

The killings of people with albinism and old people with red eyes indicate that the areas where such killings are prevalent are no more healthy communities. This means that religious institutions need to engage in curbing such killings if they have to claim efficacy to their adherents. The measure of their efficacy, Evans states, is whether they enhance or diminish human life and dignity. He clearly states: "The measure of every institution, program, policy, and system is whether it threatens or enhances the life and dignity of every person within that society" (Evans, 2006, p. 24). Since religions surrounding the areas where the killings of people with albinism belong to people of those areas, the writer suggests that such religions will be beneficial to people of those areas if they purport to enhance life instead of being silent as if nothing is happening to their adherents.

Another point must be insisted here: the sacredness and goodness of difference. As stated above, the killers of people with albinism use the rare difference to construct beliefs for their own material benefits. In doing that, the killers violate God's own plan for the existence of difference. The theologian Thomas Reynolds states: "Beings are not uniformly the same but different. Where the biblical notion of creation pushes further is in its declaration that this difference is good. All the Genesis 1 account concludes with God's affirmation. All the elements of existence - from the star-ridden firmament of the heavens, the dry earth, and the watery seas, to the thriving plans, animals and human beings - are different and good. The universe is blessed as a milieu of astounding abundance and staggering complexity and diversity” (Raynolds, 2008, p. 160). Raynolds' statement above indicates that the use of difference to threaten the life and dignity of other human beings is contrary to 
God's will for creation and should be vehemently rejected by all religions that claim to worship God. Therefore, the role of religions to enhance life instead of threatening it in the name of difference remains the major prerequisite for its efficacy in the midst of their adherents.

\section{Conclusion}

The whole of the above account indicates that a person with albinism is precious before the Creator (Isaiah 43: 4) in a similar way to the one without albinism. The creation of difference is just a gift from the Creator to enable the world to be in disproportionate relationship for the Creator's own sake. If this holds any truth, then religions in places where people with albinism are hacked and chased like animals because of their differences in skin color, which need to understand that skin disability is fundamentally the will of the Creator. In such understanding, they should welcome people with skin disability in their religious communities.

The words of Raynolds, as quoted from Jean Vanier (2005), are quite illuminating regarding the issue of disability. Raynolds (2008) states:

In the midst of our broken world our communities and our families are called to become like small oases, humble places of love where we try to live covenant between us and in solidarity with the weak and the suffering throughout the world. Our [religious] communities are not cut off from the world. They are open to others in the local community and neighborhood, as well as to those who are far away. We are all part of one and the same body, each one of us, in his/her wn way, breathing the same breath of the spirit of God” (pp. 249 - 250).

In a single sentence, Reynolds' statement above tells religions that they need to accept differences as a blessing and teach their adherents as such without entertaining any kind of discrimination based on any God-given difference among human beings. Religions need to welcome people as they are and respect their value and dignity regardless of their human condition. In doing that, hopefully, religions will fulfill the wills of the Creator and the purpose of the Creator to created human beings.

\section{References}

European Parliament. (2008). Albino Killings in Tanzania. The Official Journal of the European

Evans, Bernard F. (2006). Lazarus at the Table: Catholics and Social Justice. Collegeville, Minnesota: Liturgical Press.

Magessa, Boniface. (2008). The Killing of Albino in Tanzania. Retrieved from http://magessabm.blogspot.com/2008/12/killings-of-albino-in- tanzania.html

Magram, Khalid. (2009). Albinism Murder Trial begins in Tanzania. Digital Journal. Retrieved from http://www.digitaljournal.com/article/273834?tp=1

Nyaundi, Nehemia. (2010). The Phenomenon of Violence in Eastern Africa. African Theology comes of Age: Revisiting 20 Years of the Theology of the Ecumenical Symposium of Eastern Africa Theologians (ESEAT). (pp. 123-131). Nairobi: Paulines Publications Africa.

Raynolds, Thomas. (2008). Vulnerable Communion: A Theology of Disability and Hospitality. Grand Rapids, Michigan: Branzos Press.

Tanner, Ralph. (2010). Ideology and the Killing of Albinos in Tanzania: A Study in Cultural Relativities. Anthropologist, 12(4), 229-236.

Union. (2013). European Parliament resolution of 4 September, 2008 on the killing of albinos in Tanzania. Retrieved from http://eur- lex.europa.eu/LexUriServ/LexUriServ.do?uri=OJ:C:2009:295E:0094:0096:EN:PDF 